\title{
Hubungan Motivasi Belajar Matematika Siswa Terhadap Hasil Belajar Matematika Pada Materi Kalkulus dan Aljabar di Kelas XI IPA SMA
}

\author{
Mohamad Syafi'i \\ STKIP Kusumanegara Jakarta \\ Jl. Raya Bogor, RT.3/RW.4, Gedong, Kec. Ps Rebo, Kota Jakarta Timur, DKI Jakarta \\ moh.syafii@stkipkusumanegara.ac.id
}

\begin{abstract}
The aim of this research is to determine the relationship between student's mathematics learning motivation and mathematics learning achievement. This research is a correlation study. Affordable population in this study was taken based on the value of UNBK in 2018/2019 in the area of East Jakarta. The samples in this study were students from MIPA D XI SMAN 105 Jakarta ( $1^{\text {st }}$ sample), XI IPA 2 MAN 2 Jakarta (2 ${ }^{\text {nd }}$ sample), and XI IPA 3 at Budhi Warman 2 High School Jakarta ( $3^{\text {rd }}$ sample). Data analysis in this study used a simple linear regression test to determine the significance of the correlation between students' mathematics learning motivation and student mathematics learning achievement. The results showed that there was a positive correlation between students' mathematics learning motivation and mathematics learning achievement. This can be proven by the value of the correlation coefficient obtained in each class used as a research sample. Correlation coefficient values in first sample $r_{x y}=0.945$ with a coefficient of determination $89.4 \%$, Correlation coefficient values in $2^{\text {nd }}$ sample $r_{x y}=0.963$ with a coefficient of determination $92.8 \%$, while in $3^{\text {rd }}$ sample a correlation coefficient value of $r_{x y}=0.857$ with a coefficient of determination $73.4 \%$. The conclusion from this study is that there is a positive relationship between students' mathematics learning motivation and mathematics learning achievement.
\end{abstract}

Keywords: Mathematics learning achievement, correlation, mathematics learning motivation

\begin{abstract}
Abstrak
Tujuan dalam penelitian ini adalah untuk mengetahui hubungan antara motivasi belajar matematika peserta didik terhadap hasil belajar matematika peserta didik. Penelitian merupakan penelitian korelasi. Populasi terjangkau pada penelitian ini diambil berdasarkan nilai UNBK pada tahun 2018/2019 di daerah Jakarta Timur. Adapun sampel pada penelitian ini adalah peserta didik dari XI MIPA D SMAN 105 Jakarta (sampel 1), XI IPA 2 MAN 2 Jakarta (sampel 2), dan XI IPA 3 SMA Budhi Warman 2 Jakarta (sampel 3). Analisis data pada penelitian ini menggunakan uji regresi linier sederhana untuk mengetahui signifikansi korelasi antara motivasi belajar matematika siswa dengan hasil belajar matematika siswa. Hasil penelitian menunjukkan bahwa terdapat korelasi positif antara motivasi belajar matematika peserta didik terhadap hasil belajar matematika. Hal ini dapat dibuktikan dengan nilai koefisien korelasi yang didapatkan pada setiap kelas yang dijadikan sampel penelitian. Nilai koefisien korelasi pada sampel $r_{x y}=0,945$ dengan koefisien determinasi 89,4 \%, Nilai koefisien korelasi pada sampel $2 \mathrm{r}_{\mathrm{xy}}=0,963$ dengan koefisien determinasi 92,8 \%, sedangkan pada sampel 3 diperoleh nilai koefisien korelasi $r_{x y}=0,857$ dengan koefisien determinasi 73,4 \% . Kesimpulan dari penelitian ini adalah terdapat hubungan positif antara motivasi belajar matematika peserta didik terhadap hasil belajar matematika.
\end{abstract}

Kata Kunci: Hasil belajar matematika, Korelasi, Motivasi belajar matematika.

Copyright (c) 2021 Mohamad Syafi'i

$\triangle$ Corresponding author: Mohammad Syafi'i

Email Address: moh.syafii@ stkipkusumanegara (Jl. Raya Bogor, RT.3/RW.4, Jakarta)

Received 01 Juli 2020, Accepted 02 Agustus 2020, Published 03 Januari 2021

\section{PENDAHULUAN}

Pembelajaran Matematika di sekolah mempunyai peran penting dalam mengembangkan proses pola pikir matematis siswa. Seiring dengan banyaknya sekolah yang menerapkan kurikulum 2013, 
maka diharapkan adanya perubahan dalam pelaksanaan pembelajaran. Pada saat ini guru harus dapat membangkitkan keaktifan siswa dalam kelas sehingga guru pada saat ini dituntut lebih kreatif dan inovatif dalam menyajikan materi dengan pendekatan scientific yang terdiri dari pengamatan, menanyakan, mengumpulkan informasi, menalar dan mengkomunikasikan.

Masalah yang timbul dalam proses pembelajaran biasanya disebabkan kurangnya hubungan komunikatif antara guru dengan siswa, serta interaksi siswa dengan siswa lainnya sehingga proses interaksi menjadi vakum, dan proses pembelajaran menjadi membosankan. Kondisi demikian tentunya membuat motivasi belajar siswa menjadi semakin rendah, sehingga perlu adanya pemilihan model pembelajaran yang baik agar hasil optimal dapat diperoleh. Karena hal ini dapat merangsang motivasi siswa untuk mengembangkan pengetahuannya tanpa merasa bahwa materi yang diberikan oleh guru menyulitkan dan membosankan.

Keberhasilan dalam mempelajari ilmu matematika dapat dilihat dari pencapaian hasil belajar yang diperoleh peserta didik. Hasil belajar merupakan hal yang sangat penting sebagai indikator keberhasilan belajar. Peserta didik sebagai objek utama dalam kegiatan belajar di sekolah mempunyai karakteristik yang berbeda satu sama lain sehingga terdapat perbedaan hasil belajar. Pada kenyataannya masih banyak peserta didik yang memiliki hasil belajar matematika yang rendah. Rendahnya hasil belajar matematika yang diperoleh peserta didik dalam kegiatan pembelajaran dipengaruhi oleh banyak faktor baik dari dalam maupun dari luar diri peserta didik. Beberapa faktor dari dalam diri peserta didik adalah kesehatan, minat, bakat, perhatian, motivasi, kesiapan, tingkat kecerdasan, aktivitas belajar peserta didik dan lain-lain. Faktor dari luar diri peserta didik adalah guru, metode pembelajaran, fasilitas belajar, kondisi lingkungan dan sebagainya. Agar hasil belajar matematika dan kualitas belajar dapat meningkat maka faktor-faktor tersebut harus diperbaiki.

Istilah motivasi berasal dari kata motif yang dapat diartikan sebagai kekuatan yang terdapat dalam diri individu, yang menyebabkan individu tersebut bertindak atau berbuat. Motif tidak dapat diamati secara langsung, tetapi dapat diinterpretasikan dalam tingkah lakunya berupa rangsangan, dorongan atau pembangkit tenaga munculnya suatu tingkah laku tertentu (Uno, 2017). Menurut Frederick J. Mc Donald, Motivasi belajar merupakan suatu perubahan tenaga di dalam diri seseorang (pribadi) yang ditandai dengan timbulnya perasaan dan reaksi untuk mencapai tujuan. Sedangkan menurut Clayton Alderfer Motivasi belajar adalah kecenderungan siswa dalam melakukan kegiatan belajar yang didorong oleh hasrat untuk mencapai prestasi atau hasil belajar sebaik mungkin. Adapun menurut Abraham Maslow motivasi belajar juga merupakan kebutuhan untuk mengembangkan kemampuan diri secara optimum, sehingga mampu berbuat yang lebih baik, berprestasi dan kreatif (Drs. Nashar, 2004).

Rendahnya hasil belajar matematika siswa bisa disebabkan oleh faktor motivasi belajar. Motivasi belajar peserta didik dapat dilihat dari beberapa hal, antara lain: (1) minat dan perhatian siswa terhadap pelajaran, (2) semangat siswa untuk melakukan tugas-tugas belajarnya, (3) tanggungjawab siswa dalam mengerjakan tugas-tugas belajarnya, (4) reaksi yang ditunjukan siswa terhadap stimulus 
yang diberikan guru, (5) rasa senang dan puas dalam mengerjakan tugas yang diberikan (Hamdu, G., dan Agustina, 2011).

Hasil penelitian menunjukkan bahwa sebagian besar peserta didik memiliki motivasi belajar yang tinggi pada mata pelajaran yang disenangi akan berdampak besar pada hasil belajar mata pelajaran tersebut. Rata-rata peserta didik yang memiliki motivasi yang sangat tinggi dan memiliki indeks hasil belajar yang baik bahkan sangat baik (Warti, 2018). Tinggi rendahnya hasil belajar matematika siswa dalam kegiatan pembelajaran dipengaruhi faktor dari dalam maupun luar diri peserta didik. Tentunya, pada penelitian kali ini lebih memfokuskan pada faktor motivasi belajar siswa, hal ini diasumsikan oleh peneliti jika siswa yang memiliki motivasi belajar yang tinggi cenderung hasil belajarnya akan tinggi pula, sebaliknya siswa yang motivasi belajarnya rendah akan rendah pula hasil belajarnya. Karena itu peran motivasi menjadi sangat penting, karena motivasi merupakan penggerak atau pendorong untuk melakukan tindakan tertentu. Berdasarkan latar belakang di atas, maka peneliti tertarik melakukan penelitian dengan judul hubungan motivasi belajar matematika siswa terhadap hasil belajar matematika siswa.

\section{METODE}

Sasaran Penelitian adalah di 3 Sekolah Menengah Atas (SMA) di lingkup Kecamatan Pasar Rebo dan Kecamatan Ciracas Kota Administrasi Jakarta Timur. Penelitian ini dilaksanakan pada bulan Maret 2019 sampai Mei 2019. Jenis Penelitian ini merupakan penelitian kuantitatif dengan pendekatan korelasi. Penelitian korelasional merupakan peneltian yang dilakukan untuk mengetahui tingkat hubungan antara dua variabel atau lebih, tanpa melakukan perubahan, tambahan, dan manipulasi terhadap data yang sudah ada (Arikunto, 2013). Teknik analisis data pada penelitian ini menggunakan uji regresi linier sederhana berbantuan SPSS 16.0 for windows. Adapun langkahlangkah analisis data yang dilakukan adalah diawali dengan deskripsi data, dilanjutkan uji prasyarat yaitu uji normalitas dan uji linieritas dan didapatkan model persamaan regresi. Berdasarkan koefisien regresi yang diperoleh akan didapatkan nilai koefisien korelasi dan koefisien determinasi, pada penelitian ini taraf signifikansi $(\alpha)$ yang digunakan adalah 0.05 .

Populasi pada penelitian ini adalah siswa kelas XI MIPA SMA/MA di kecamatan Pasar rebo atau Kecamatan Ciracas Kota Administrasi Jakarta timur dengan minimal terdapat 3 kelas paralel. Pada penelitian ini populasi akan dibagi menjadi 3 kelompok berdasarkan nilai rata - rata UNBK tahun 2017/2018 dengan kategori tinggi, sedang, dan rendah. Setelah klaster dibentuk diambil satu sekolah secara acak dalam setiap kategori yang dikemudian dijadikan sebagai populasi terjangkau pada penelitian ini. Adapun sekolah yang menjadi populasi terjangkau adalah sebagai berikut:

1. SMAN 105 Jakarta untuk kategori tinggi

2. MAN 2 Jakarta untuk kategori sedang

3. SMA BUDHI WARMAN 2 Jakarta untuk kategori rendah Adapun sampel pada penelitian ini adalah sebagai berikut: 
Tabel 1. Sampel Penelitian

\begin{tabular}{|c|c|c|}
\hline No. & Sekolah & Kelas \\
\hline $\mathbf{1 .}$ & SMAN 105 Jakarta & XI MIPA D \\
\hline $\mathbf{2 .}$ & MAN 2 Jakarta & XI IPA 2 \\
\hline 3. & SMA BUDHI WARMAN (BW) 2 JAKARTA & XI IPA 3 \\
\hline
\end{tabular}

adapun dalam pengambilan sampel, penulis menggunakan cluster sampling technique, teknik ini merupakan teknik dengan pemilihan unit pengamatan berdasarkan klaster-klaster tertentu yang dibuat oleh peneliti. Populasi yang sudah ditentukan dibagi atas beberapa klaster kemudian sampel akan dipilih dari beberapa klaster yang sudah dibentuk (Lolombuan, 2017). Adapun Road Map pada penelitian ini, dapat dilihat pada gambar 1 di bawah ini:

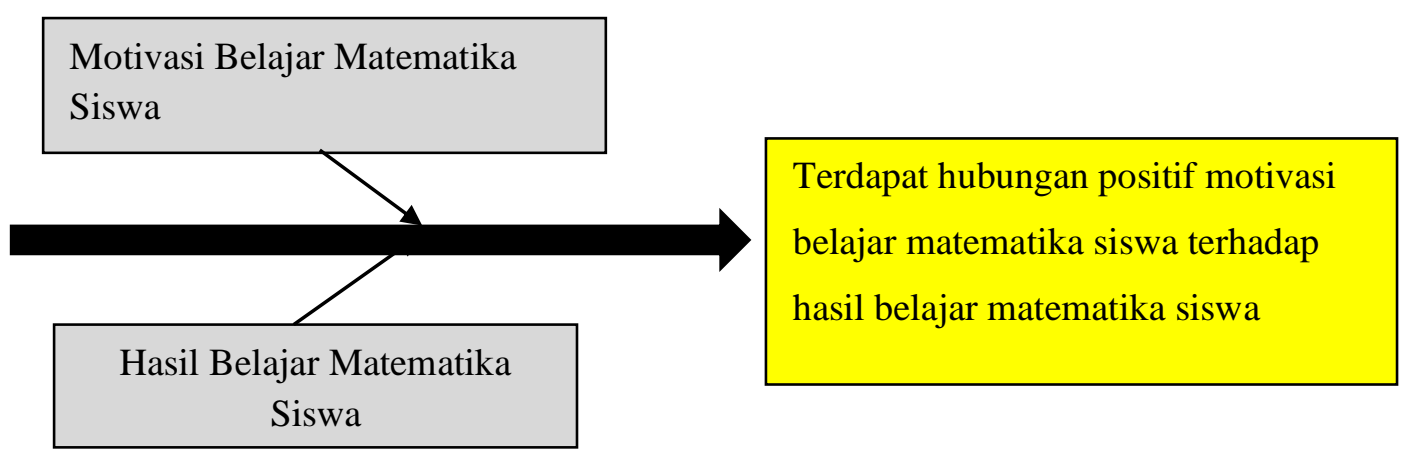

Gambar 1. Road Map Penelitian

Instrumen pada penelitian ini berupa angket atau kuesioner sebanyak 25 butir pertanyaan untuk mengukur motivasi belajar matematika siswa. Instrumen penelitian kedua berupa tes berbentuk pilihan ganda sebanyak 26 soal untuk mengukur hasil belajar matematika siswa.

Pada penelitian ini terdapat variabel independen (variabel bebas) yang sering disebut variabel stimulus atau predictor. Variabel bebas adalah variabel yang mempengaruhi dengan kata lain variabel yang menjadi sebab timbulnya variabel terikat. Adapun pengertian variabel terikat adalah variabel yang menjadi akibat karena adanya variabel bebas (Sugiyono, 2015). Adapun variabel bebas dan variabel terikat pada penelitan ini adalah sebagai berikut:

Tabel 2. Variabel Penelitian

\begin{tabular}{|c|c|c|}
\hline Jenis Peneltian & Variabel Bebas & Variabel Terikat \\
\hline Korelasional & $\begin{array}{c}\text { Motivasi belajar matematika } \\
\text { siswa }\end{array}$ & Hasil belajar matematika siswa \\
\hline
\end{tabular}

Perumusan hipotesis statistik untuk mengetahui terdapat hubungan antara motivasi belajar matematika siswa terhadap hasil belajar matematika siswa adalah sebagai berikut:

Kriteria pengujian

$H_{0}: t_{\text {hitung }} \leq t_{\text {tabel }}$ 
$H_{1}: t_{\text {hitung }}>t_{-}$tabel

dimana

$H_{0}: r_{x y} \leq 0$

$H_{1}: r_{x y}>0$

atau

$H_{0} \quad$ : Tidak terdapat hubungan yang positif motivasi belajar matematika siswa terhadap hasil belajar matematika siswa

$H_{1} \quad$ : Terdapat hubungan positif motivasi belajar matematika siswa terhadap hasil belajar matematika siswa.

Dengan $r_{x y}$ adalah koefisien korelasi hubungan antara motivasi belajar matematika siswa terhadap hasil belajar matematika siswa.

\section{HASIL DAN DISKUSI}

\section{Deskripsi Data}

Guna memperoleh gambaran mengenai pengaruh model pembelajaran Mind Mapping berbasis HOTS terhadap hasil belajar siswa pada pembelajaran matamatika, digunakan instrumen angket yang berupa daftar pertanyaan sebagai tehnik pengumpulan data motivasi belajar siswa dan tes evaluasi belajar siswa sebagai teknik pengumpulan data hasi belajar siswa. Adapun deskripsi data motivasi belajar siswa dan hasil belajar siswa adalah sebagai berikut:

Tabel 3. Deskripsi Data Motivasi Belajar Dan Hasil Belajar Siswa SMAN 105 Jakarta

\begin{tabular}{|l|l|c|}
\hline Kelas & XI MIPA D \\
\hline \multirow{3}{*}{$\begin{array}{l}\text { Motivasi } \\
\text { Belajar }\end{array}$} & Rata-rata & 75.028 \\
\cline { 2 - 3 } & Nilai Terendah & 51 \\
\cline { 2 - 3 } & Nilai Tertinggi & 93 \\
\hline \multirow{3}{*}{ Hasil Belajar } & Rata-rata & 78.19 \\
\cline { 2 - 3 } & Nilai Terendah & 51 \\
\cline { 2 - 3 } & Nilai Tertinggi & 95 \\
\hline
\end{tabular}

Tabel 4. Deskripsi Data Motivasi Belajar Dan Hasil Belajar Siswa MAN 2 Jakarta

\begin{tabular}{|l|l|c|}
\hline Kelas & & XI IPA 2 \\
\hline \multirow{3}{*}{$\begin{array}{l}\text { Motivasi } \\
\text { Belajar }\end{array}$} & Rata-rata & 70.83 \\
\cline { 2 - 3 } & Nilai Terendah & 40 \\
\cline { 2 - 3 } & Nilai Tertinggi & 93 \\
\hline \multirow{3}{*}{ Hasil Belajar } & Rata-rata & 75.6 \\
\cline { 2 - 3 } & Nilai Terendah & 50 \\
\cline { 2 - 3 } & Nilai Tertinggi & 100 \\
\hline
\end{tabular}


Tabel 5. Deskripsi Data Motivasi Belajar Dan Hasil Belajar Siswa SMA Budhi Warman 2 Jakarta

\begin{tabular}{|l|l|c|}
\hline \multicolumn{2}{|l|}{ Kelas } & XI IPA 3 \\
\hline \multirow{3}{*}{$\begin{array}{l}\text { Motivasi } \\
\text { Belajar }\end{array}$} & Rata-rata & 67.52 \\
\cline { 2 - 3 } & Nilai Terendah & 48 \\
\cline { 2 - 3 } & Nilai Tertinggi & 85 \\
\hline \multirow{3}{*}{ Hasil Belajar } & Rata-rata & 70.17 \\
\cline { 2 - 3 } & Nilai Terendah & 50 \\
\cline { 2 - 3 } & Nilai Tertinggi & 85 \\
\hline
\end{tabular}

\section{Uji Hipotesis Penelitian Berdasarkan Data yang Didapatkan di SMAN 105 Jakarta}

Berdasarkan hasil uji prasyarat untuk melakuan uji hipotesis yang sudah terpenuhi, selanjutnya dapat melakukan pengujian hipotesis. Untuk mengetahui adanya hubungan positif motivasi belajar siswa terhadap hasil belajar matematika siswa di kelas XI MIPA D SMAN 105 Jakarta, didapatkan hasil perhitungan seperti pada tabel 4 di bawah ini:

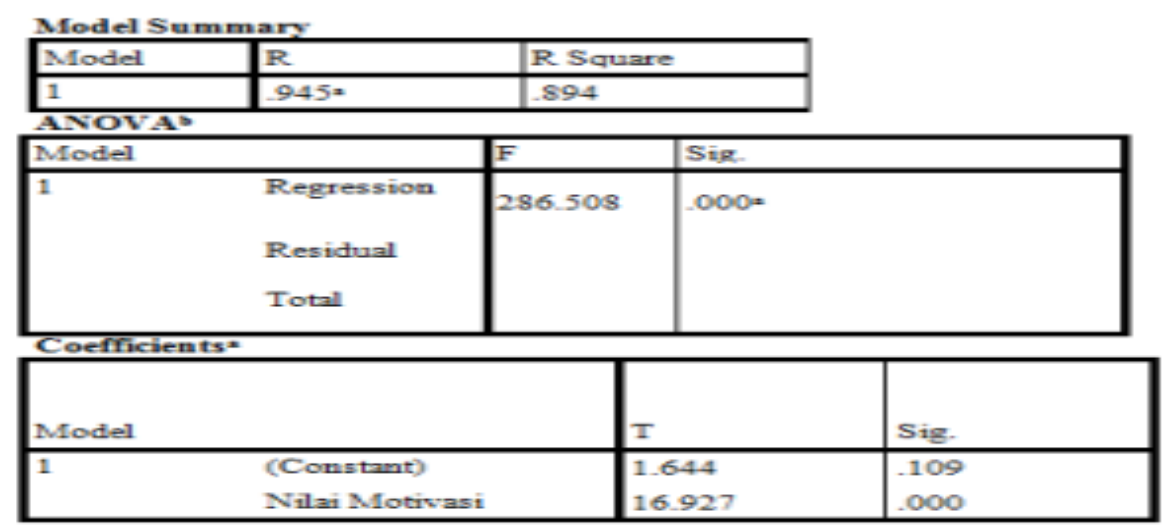

Gambar 1. Hasil Analisis Linier Regresi Sederhana Motivasi Belajar Siswa di Kelas XI MIPA D

\section{SMAN 105 Jakarta}

Berdasarkan gambar 1 di atas, perhitungan analisis Linier Regresi sederhana berbantuan SPSS diperoleh nilai signifikansi yaitu 0.000 lebih kecil dari 0.05 sehingga $H_{0}$ ditolak, Hal ini juga dikuatkan dengan nilai $t_{\text {hitung }}=16.927>t_{\text {tabel }}=1.994$. Perbandingan kedua nilai tersebut menunjukkan terdapat hubungan yang berarti antara motivasi belajar matematika siswa terhadap hasil belajar matematika siswa di kelas XI MIPA D SMAN 105 Jakarta.

Nilai koefisien korelasi yang diperoleh adalah 0.945 , maka dapat disimpulkan terdapat hubungan positif yang sangat kuat antara motivasi belajar matematika terhadap hasil belajar matematika siswa. Untuk mengetahui seberapa besar persentase hubungan antara antara motivasi belajar matematika terhadap hasil belajar matematika siswa dapat melihat nilai koefisien determinasi $\left(r^{2}\right)$ yang diperoleh. Berdasarkan hasil perhitungan diperoleh koefisien determinasi sebesar 0,894, artinya kontribusi yang diberikan motivasi belajar matematika siswa terhadap hasil belajar siswa sebesar $\mathbf{8 9 , 4 \%}$. 


\section{Uji Hipotesis Penelitian Berdasarkan Data yang Didapatkan di MAN 2 Jakarta}

Berdasarkan hasil uji prasyarat untuk melakuan uji hipotesis yang sudah terpenuhi, selanjutnya dapat melakukan pengujian hipotesis: Untuk mengetahui adanya hubungan positif motivasi belajar siswa terhadap hasil belajar matematika siswa di kelas XI IPA 2 MAN 2 Jakarta, didapatkan hasil perhitungan seperti pada tabel 5 di bawah ini:

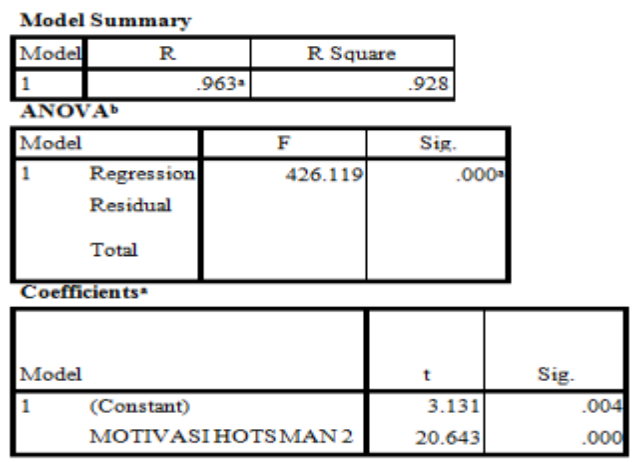

Gambar 2. Hasil Analisis Linier Regresi Sederhana Motivasi Belajar Siswa di Kelas XI IPA 2

MAN 2 Jakarta

Berdasarkan gambar 2 di atas, perhitungan analisis Linier Regresi sederhana berbantuan SPSS diperoleh nilai signifikansi yaitu 0.000 lebih kecil dari 0.05 sehingga $H_{0}$ ditolak, Hal ini juga dikuatkan dengan nilai $t_{\text {hitung }}=20.643>t_{\text {tabel }}=1.994$. Perbandingan kedua nilai tersebut menunjukkan terdapat hubungan yang berarti antara motivasi belajar matematika siswa terhadap hasil belajar matematika siswa di kelas XI IPA 2 MAN 2 Jakarta.

Nilai koefisien korelasi yang diperoleh adalah 0.963, maka dapat disimpulkan terdapat hubungan positif yang sangat kuat antara motivasi belajar matematika terhadap hasil belajar matematika siswa. Untuk mengetahui seberapa besar persentase hubungan antara antara motivasi belajar matematika terhadap hasil belajar matematika siswa dapat melihat nilai koefisien determinasi $\left(r^{2}\right)$ yang diperoleh. Berdasarkan hasil perhitungan diperoleh koefisien determinasi sebesar 0,928, artinya kontribusi yang diberikan motivasi belajar matematika siswa terhadap hasil belajar siswa sebesar $\mathbf{9 2 , 8 \%}$.

\section{Uji Hipotesis Penelitian Berdasarkan Data yang Didapatkan di SMA Budhi Warman 2 Jakarta}

Berdasarkan hasil uji prasyarat untuk melakuan uji hipotesis yang sudah terpenuhi, selanjutnya dapat melakukan pengujian hipotesis: Untuk mengetahui adanya hubungan positif motivasi belajar siswa terhadap hasil belajar matematika siswa di kelas XI IPA 3 SMA Budhi Warman 2 Jakarta, didapatkan hasil perhitungan seperti pada Gambar 3 di bawah ini 


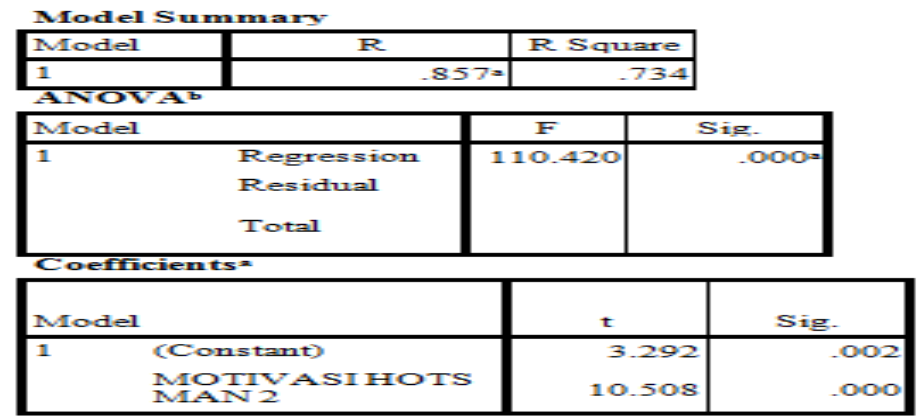

Gambar 3. Hasil Analisis Linier Regresi Motivasi Belajar Siswa di Kelas XI IPA 3 SMA Budhi Warman 2 Jakarta

Berdasarkan gambar 3 di atas, perhitungan analisis Linier Regresi sederhana berbantuan SPSS diperoleh nilai signifikansi yaitu 0.002 lebih kecil dari 0.05 sehingga $H_{0}$ ditolak, Hal ini juga dikuatkan dengan nilai $t_{\text {hitung }}=3.292>t_{\text {tabel }}=1.989$. Perbandingan kedua nilai tersebut menunjukkan terdapat hubungan yang berarti antara motivasi belajar matematika siswa terhadap hasil belajar matematika siswa di kelas XI IPA 3 SMA Budhi Warman 2 Jakarta. Nilai koefisien korelasi yang diperoleh adalah 0.857 , maka dapat disimpulkan terdapat hubungan positif yang sangat kuat antara motivasi belajar matematika terhadap hasil belajar matematika siswa.

Untuk mengetahui seberapa besar persentase hubungan antara antara motivasi belajar matematika terhadap hasil belajar matematika siswa dapat melihat nilai koefisien determinasi $\left(r^{2}\right)$ yang diperoleh. Berdasarkan hasil perhitungan diperoleh koefisien determinasi sebesar 0,734, artinya kontribusi yang diberikan motivasi belajar matematika siswa terhadap hasil belajar siswa sebesar $73,4 \%$.

\section{Diskusi}

Penelitian ini memberikan gambaran tentang hubungan antara motivasi belajar matematika siswa dengan hasil belajar siswa. Hasil belajar merupakan realisasi dari kecakapan-kecakapan potensial atau kapasitas yang dimiliki peserta didik, baik perilaku dalam bentuk penguasaan, pengetahuan keterampilan berpikir maupun keterampilan motorik. Evaluasi atau penilaian merupakan alat ukur untuk mengukur sampai dimana tujuan pengajaran telah tercapai, baik dari siswa maupun guru (Syaodih, 2004).

Adapun motivasi merupakan dorongan untuk mencapai tujuan. Motivasi merupakan kekuatan dalam diri seorang peserta didik yang merupakan dorongan untuk mencapai tujuan yaitu memperoleh hasil belajar yang baik sesuia dengan usaha yang dilakukan. Motivasi itu sendiri timbul karena adanya dua sumber yaitu dari dalam diri sendiri yang dikenal dengan motivasi internal dan sumber dari luar yang dikenal dengan motivasi eksternal, yaitu dorongan dan semangat yang timbul karena dipengaruhi oleh teman, atau karena terdesak oleh adanya kebutuhan (Arikunto, 2017). 
Berdasarkan penelitian yang telah dilakukan di tiga kelas dengan sekolah yang berbeda didapatkan adanya korelasi atau hubungan antara motivasi belajar matematika terhadap hasil belajar matematika siswa, Adapun seberapa besar kontribusi motivasi belajar matematika terhadap hasil belajar matematika dapat dilihat pada tabel 7 di bawah ini:

Tabel 7. Pengaruh Motivasi Belajar Matematika Terhadap Hasil Belajar Matematika

\begin{tabular}{|c|c|c|c|}
\hline No & Sekolah & Kelas & Besar Kontribusi* \\
\hline & SMAN 105 Jakarta & XI MIPA D & $89,4 \%$ \\
\hline 2. & MAN 2 Jakarta & XI IPA 2 & $92,8 \%$ \\
\hline 3. & SMA Budhi Warman 2 Jakarta & XI IPA 3 & $72,8 \%$ \\
\hline
\end{tabular}

*Keterangan: Kontribusi motivasi belajar matematika siswa terhadap hasil belajar matematika siswa

Berdasarkan tabel 7 diatas, dapat dilihat bahwa terdapat kontribusi yang positif antara motivasi belajar matematika siswa terhadap hasil belajar matematika siswa. Adapun kontribusi motivasi belajar matematika terhadap hasil belajar matematika siswa di kelas XI MIPA D SMAN 105 Jakarta sebesar 89,4\%, sedangkan di kelas XI IPA 2 MAN 2 Jakarta sebesar 92,8\%, dan XI IPA 3 SMA Budhi Warman 2 Jakarta sebesar 72,8\%. Selain itu, berdasarkan perhitungan uji-t dari data yang didapatkan diperoleh bahwa motivasi belajar matematika siswa mempunyai pengaruh yang positif terhadap hasil belajar matematika siswa.

\section{KESIMPULAN}

Berdasarkan dari hasil penelitian, analisis data, dan pembahasan diperoleh kesimpulan bahwa terdapat hubungan positif yang signifikan antara motivasi belajar matematika siswa terhadap hasil belajar matematika siswa di setiap kelas yang menjadi sampel. Hal ini juga sejalan dengan beberapa hasil penelitian terdahulu; Secara teoritis motivasi siswa juga merupakan salah satu faktor yang juga mempengaruhi keberhasilan belajar. Apabila seorang siswa berpedoman pada dimensi-dimensi motivasi maka akan menimbulkan hasil belajar yang sangat baik untuk siswa (Zamsir, L. M., dan Fajrin, 2017). Motivasi belajar yang tercermin dari indikator durasi kegiatan, frekuensi kegiatan, presistensi, devosi dan pengorbanan, ketabahan, keuletan dan kemampuan, tingkat inspirasi, tingkatan kualifikasi hasil, serta arah sikap terhadap sasaran kegiatan memiliki peran penting terhadap hasil belajar siswa (Andriani \& Rasto, 2019).

\section{UCAPAN TERIMA KASIH}

Dengan selesainya penelitian ini, saya ucapkan terimakasih kepada dosen-dosen program studi Pendidikan Matematika STKIP Kusumanegara, Jakarta, Kepala Sekolah dan guru - guru SMAN 
105 Jakarta, MAN 2 Jakarta, XI IPA 3 SMA Budhi Warman Jakarta, dan seluruh pihak yang telah membantu dalam pelaksanaan kegiatan ini, sehingga terlaksana dengan baik, dan lancar.

\section{DAFTAR PUSTAKA}

Andriani, R., \& Rasto, R. (2019). Motivasi belajar sebagai determinan hasil belajar siswa. Jurnal Pendidikan Manajemen Perkantoran, 4(1), 80. https://doi.org/10.17509/jpm.v4i1.14958

Arikunto, S. (2013). Prosedur Penelitian: Suatu Pendekatan Praktik. Rineka Cipta.

Arikunto, S. (2017). Pengembangan Instrumen Penelitian dan Penilaian Program. Pustaka Belajar.

Drs. Nashar. (2004). Peranan Motivasi dan Kemampuan Awal dalam Kegiatan Pembelajaran. Jakarta.

Hamdu, G., dan Agustina, L. (2011). Pengaruh Motivasi Belajar Siswa terhadap Prestasi Belajar IPA di Sekolah Dasar. Jurnal Penelitian Pendidikan, 12(1), 90-96.

Lolombuan, J. H. (2017). Statistika bagi Peneliti Pendidikan. Penerbit Andi.

Sugiyono. (2015). Statistika untuk penelitian. Alfabeta.

Syaodih, S. N. (2004). Landasan Psikologi Prosedur Pendidikan. Remaja Rosda Karya.

Uno, H. B. (2017). Teori Motivasi dan Pengukurannya. Bumi Aksara.

Warti, E. (2018). Pengaruh Motivasi Belajar Siswa terhadap Hasil Belajar Matematika Siswa di SD Angkasa 10 Halim Perdana Kusuma Jakarta Timur. Mosharafa: Jurnal Pendidikan Matematika, 5(2), 177-185. https://doi.org/10.31980/mosharafa.v5i2.273

Zamsir, L. M., dan Fajrin, P. (2017). Pengaruh Motivasi Belajar Terhadap Hasil Belajar Matematika Siswa SMPN 1 Lawa. Jurnal Pendidikan Matematika. Jurnal Pendidikan Matematika, 6(2), 170-181. 